\title{
Observations on Pod Borer Oviposition and Infestation of Pigeonpea Varieties'
}

\author{
Carlos Cruz ${ }^{2}$
}

\begin{abstract}
Thirteen varieties of pigeonpea (Cajanus cajan (L.) Millsp.) were planted to determine pod borer oviposition preferences and infestation percentages. Etiella zinckenella and Heliothis virescens were the predominant species. Oviposition of Heliothis began on flower buds but pods were preferred where available except for varieties Florido, Trinidad 5690 and Trinidad 6222 where a similar preference for bud and pods was recorded. Variety Guamá particularly was less attractive for oviposition. Varieties Saragateado, Florido and Totiempo showed highest infestation rates throughout the season.
\end{abstract}

\section{INTRODUCTION}

Pigeonpeas (Cajanus cajan (L.) Millsp.) are grown as an annual crop throughout Puerto Rico. It is a crop with increasing economic importance due to its high nutritive value $(2,17)$ and high palatability. Before 1940 most of the production was for family consumption and a limited amount was sold in the local market. Since then, however, commercial production has been increasing steadily. Lloréns and Olivieri (8) found in 1955 that 75 percent of the production of green pigeonpeas was sold through marketing outlets operating in Puerto Rico. The farm value of pigeonpeas in 1945 was only $\$ 693,000$ according to the same authors. In $1971(1)$, this value had increased to over $\$ 3.5$ million.

The planting season of pigeonpea is generally from April to August and the harvesting of the crop in the green stage is mainly from December to February. Of the many varieties grown in Puerto Rico, the commercial variety, Kaki, is harvested in December, while Saragateado is harvested from February to March.

The pods, buds and flowers of this crop are attacked by the larvae of a number of insect pests. According to Wolcott (16), the most important are: the Caribbean pod borer, Fundella pellucens Zeller; the lima bean pod borer, Etiella zinckenella (Treitschke); the bean pod borer, Maruca testulalis (Geyer); the corn earworm, Heliothis zea (Boddie) and the tobacco budworm $^{3}$, Heliothis virescens ( $\mathrm{F}$.).

${ }_{1}^{1}$ Manuscript submitted to Editorial Board February 11, 1974.

${ }^{2}$ Assistant Entomologist, Isabela Agricultural Experiment Substation, Agricultural Experiment Station, Mayagüez Campus, University of Puerto Rico, Río Piedras, P.R.

Common names taken from Ent. Soc. Amer. Bull. 11 (4): 287-320, 1965, with the exception of the bean pod borer. 
Actual figures on losses due to pod borer damage are not available for Puerto Rico. Pérez-Escolar found a marked difference in yield of green peas of approximately 2 to 1 between sound and infested pods (12). Also, economic losses may occur due to the partial or entire destruction of the peas by the feeding habits of the larvae and the dropping of buds, flowers and pods.

Control by chemical means has been the only method used to control these insects. The search for resistance to pigeonpea pests in commercial, introduced, and newly developed varieties might result in providing a permanent and less expensive solution.

Of the above-mentioned pod borers affecting pigeonpeas, studies have been conducted mainly with regard to resistance of corn to Heliothis spp. by Guerra and Shaver (4), cotton by Lukefahr and Martin $(9,10)$, and sorghum by Painter (11). No work on resistance has been conducted in Puerto Rico. Reports have been published on the biology and parasites by Leonard and Mills $(6,7)$, Scott (13) and Wolcott $(14,16)$; host plants by Wolcott (15), and the control and damage of some of these insects by Cruz (3), Leonard and Mills (6), Wolcott (16), Latta (5), and Scott (13).

No information appears to have been published regarding varietal resistance to attack and resultant damage caused by pigeonpea pod borers. The objectives of this study were to determine the rate of oviposition and infestation by pod borers in a number of pigeonpea varieties.

\section{MATERIALS AND METHODS}

Field collections of mature pods were made from December 1968 to November 1969 in Isabela. Random samples of mature pods were taken when available at different intervals throughout the year. The number of larvae in each sample was recorded and each identified to species.

Maximum and minimum temperatures for the year at the Isabela Substation average 85 and $66^{\circ} \mathrm{F}$, respectively, and the annual average rainfall is 65.28 inches.

Thirteen varieties or lines were planted at the Isabela Substation for varietal trials and kept under observation from the time of flowering to the green pea harvest stage. Five of the varieties, Kaki, Florido, Totiempo, Saragateado, and Guamá were commercial lines available in Puerto Rico; three were from Trinidad (Trinidad 6221, 6222, and 5690) and five were irradiated lines developed by this Station. Each variety was planted in plots consisting of four rows 4 feet apart and 20 feet long, replicated five times in a randomized complete block design.

Oviposition preference on buds and pods for the 13 varieties was determined by counting all the eggs found in 6 branches taken at random from uniform plots (stand and bloom) of each variety. The percentage of 
larval infestation for each variety was determined by harvesting the mature pods of the two center rows of each plot.

Data were subjected to the analysis of variance to determine the statistical significance of the oviposition preference and infestation percentage among the varieties.

\section{RESULTS AND DISCUSSION}

RELATIVE IMPORTANCE OF THE SPECIES INVOLVED

The species causing the damage were Heliothis virescens and Etiella zinckenella. Larvae of Heliothis zea occurred rarely. Fundella pellucens and

\begin{tabular}{|c|c|c|}
\hline Month & Pods & Infestation \\
\hline & Number & Percent \\
\hline December & - & - \\
\hline January & 140 & 21 \\
\hline February & 35 & 43 \\
\hline March & 100 & 72 \\
\hline April & 100 & 91 \\
\hline May & 106 & 83 \\
\hline June & - & - \\
\hline July & 54 & 37 \\
\hline August & 284 & 30 \\
\hline September & 275 & 12 \\
\hline October & - & - \\
\hline November & 30 & 40 \\
\hline
\end{tabular}

1 Percentage of both species collectively.

2 Based on pods collected from different varieties.

Maruca testulalis were not found infesting pigeonpeas during the period of study. Etiella zinckenella predominated, perhaps due to a heavy infestation of this insect in a plantation of Tephrosia vogelii which surrounded the experimental plots.

Different percentages of larval infestation were recorded throughout the year (table 1). Heliothis virescens was predominant during the first months of the season (December to March). From April to October Etiella increased. It is pertinent to mention that stored dry pods had a heavy infestation of Etiella, the only species of the pod borers observed.

\section{VARIETAL RESISTANCE}

Oviposition of Heliothis spp. started with the appearance of the first flower buds and continued throughout pod setting and development 
(table 2). The most eggs laid on flower buds were recorded on varieties Florido and Trinidad 6222. Variety Guamá was least attractive for oviposition on flower buds. On the other varieties, Heliothis preferred to oviposit on the pods when these were available, ovipositing as many as 23 eggs per pod in some instances, as soon as these appeared. The most eggs laid on pods were recorded on variety Totiempo, with an average of 165 eggs, while an average of only 21 eggs were recorded on the flower buds of the same variety. A similar preference for flower bud and pod oviposition were re-

TABLE 2.-Mean oviposition 1 of Heliothis spp. and percentage infestation ${ }^{2}$ by larvae of Heliothis spp. and Etiella zinckenella on varieties of pigeonpeas at Isabela, P.R., 1969

\begin{tabular}{lrccc}
\hline \multirow{2}{*}{ Variety } & \multicolumn{3}{c}{ Oviposition } & Pod \\
\cline { 2 - 4 } & Buds & Pods & Total & \\
\cline { 2 - 4 } infestation \\
\hline Kaki & Number & Number & Number & Percent \\
Saragateado & $7.83 \mathrm{a}$ & $83.50 \mathrm{abc}$ & $91.33 \mathrm{a}$ & $50.1 \mathrm{ad}$ \\
Guamá & $10.66 \mathrm{a}$ & $124.00 \mathrm{abc}$ & $134.66 \mathrm{ac}$ & $89.7 \mathrm{bc}$ \\
Florido & $1.33 \mathrm{a}$ & $42.50 \mathrm{ab}$ & $43.83 \mathrm{a}$ & $49.6 \mathrm{ad}$ \\
Totiempo & $115.66 \mathrm{~b}$ & $138.66 \mathrm{ac}$ & $254.33 \mathrm{~b}$ & $96.1 \mathrm{c}$ \\
Trinidad 6221 & $21.33 \mathrm{a}$ & $165.00 \mathrm{c}$ & $186.33 \mathrm{bc}$ & $80.4 \mathrm{bc}$ \\
Trinidad 6222 & $13.50 \mathrm{a}$ & $38.83 \mathrm{~b}$ & $52.33 \mathrm{a}$ & $79.1 \mathrm{abc}$ \\
Trinidad 5690 & $54.00 \mathrm{c}$ & $33.83 \mathrm{~b}$ & $87.83 \mathrm{a}$ & $81.1 \mathrm{bc}$ \\
Line 5 & $24.83 \mathrm{ac}$ & $44.66 \mathrm{ab}$ & $69.50 \mathrm{a}$ & $74.3 \mathrm{bcd}$ \\
Line 7 & $6.66 \mathrm{a}$ & $52.00 \mathrm{ab}$ & $58.66 \mathrm{a}$ & $48.6 \mathrm{ad}$ \\
Line 9 & $7.50 \mathrm{a}$ & $51.00 \mathrm{ab}$ & $58.50 \mathrm{a}$ & $60.8 \mathrm{ab}$ \\
Line 12 & $12.83 \mathrm{a}$ & $68.66 \mathrm{ab}$ & $81.50 \mathrm{a}$ & $64.7 \mathrm{ab}$ \\
Line 17 & $10.33 \mathrm{a}$ & $43.00 \mathrm{ab}$ & $53.33 \mathrm{a}$ & $62.8 \mathrm{ab}$ \\
& $8.50 \mathrm{a}$ & $58.50 \mathrm{ab}$ & $67.00 \mathrm{a}$ & $60.0 \mathrm{ab}$ \\
\hline
\end{tabular}

${ }_{1}^{1}$ Mean number of eggs of 6 observations per variety. Each observation was on a 10-inch pod bearing branch. Means followed by the same letter are not significantly different at the 5-percent level.

2 Mean of 5 observations per variety.

corded on varieties Florido, Trinidad 5690, and Trinidad 6222. The total number of eggs deposited varied aunong the varieties. Variety Guamá was the least attractive, whereas Florido, Totiempo and Saragateado were the most. Varieties Kaki and the new lines showed moderate attraction. Oviposition of Etiella was not recorded due to the difficulty in finding the eggs, a few of which were found incrusted beneath the calyx of flowers.

Average percentage of larval infestation among the varieties ranged from 48 (Line 5) to 96 (Florido) of the pods harvested (table 2). In general, the highest egg oviposition resulted in the highest larval pod infestation. Varieties Saragateado, Florido, and Totiempo had the highest percentage of larval infestation. It should be mentioned that these are late varieties 
and consequently harvested late coincident with the heaviest infestation of the season.

These results show a difference among pigeonpea varieties regarding oviposition or resistance to the attack by pod borers. Preliminary observations revealed that oviposition preference was significant among the varieties. No data is available, however, on the economic significance of this apparent resistance. Further investigation thus will be needed to determine resistance in terms of losses. So many eggs are deposited on the buds and pods that even a significant reduction in egg laying may be insufficient to reduce infestation of the mature pods. In this study no estimates were made of the reduction in mature pod production caused by these borers. There may be need to conduct studies on the antibiosis of the varieties to the insects.

\section{RESUMEN}

Se determinó el grado de infestación causado por los barrenadores de la vaina del gandur en la Subestación de Isabela. También se tomó nota de las especies presentes.

Se sembraron 13 variedades de gandur para determinar la preferencia para la oviposición de estos insectos y su porcentaje de infestación. De las cinco especies de barrenadores de la vaina del gandur informados solo Etiella zinckenella y Heliothis virescens fueron predominantes.

La oviposición de Heliothis empezó en los capullos, pero luego el insecto prefirió las vainas, con la excepción de las variedades Florido, Trinidad 5690 y Trinidad 6222 en las que no se observó preferencia definida. La variedad Guamá arrojó el menor grado de atracción para ovipositar; sin embargo, esto no constituyó un grado inferior de infestación con respecto a las demás variedades. Las variedades Saragateado, Florido y Totiempo fueron las más atacadas.

\section{LITERATURE CITED}

1. Anónimo, Anuario de Estadísticas de Puerto Rico, Depto. de Agricultura, 1972.

2. Axtmayer, J. H. and Cook, D. H., Manual de bromatologia, Oficina Sanitaria Panamericana, Washington, D.C., Pub. Núm. 186, 181-2, 1942.

3. Cruz, C., Tephrosia seed infestation and losses caused by the lima bean pod borer, Etiella zinckenella (Treit.), J. Univ. P.R. 54(3) : 285, 1970.

4. Guerra, A. A., and Shaver, T. N., Feeding stimulants from plants for larvae of the tobacco budworm and bollworm, J. Econ. Entomol., 62(1): 98-100, 1969.

5. Latta, R., Methyl bromide fumigation for destruction of pod borer larvae, $J$. Econ. Entomol., 33(1): 176-9, 1940.

6. Leonard, M. D. and Mills, A. S., A preliminary report on the lima bean podborer and other legume pod-borers in Puerto Rico, J. Econ. Entomol. 24(2): 466-73, 1931.

7. -,- , The eggs of the lima bean pod borer in Puerto Rico, J. Econ. Entomol. $24(3)$ : $763,1931$.

8. Lloréns, A. D. and Olivieri, J. A., Producción y mercadeo del gandur en Puerto Rico, Bol. 138, Est. Exp. Agrí, Univ. de P.R., 1957.

9. Lukefahr, M. J. and Martin, D. F., Cotton plant pigments as a source of resistance to the bollworm and tobacco budworm, J. Econ. Entomol. 59(1): 176-9, 1966.

10. - - - - - and Meyer J. R., Plant resistance to five lepidoptera attacking cotton, J. Econ. Entomol. 58(3): 516-8, 1965. 
11. Painter, R. H., Insect resistance in crop plants, 1st. paperback ed., 520 pp., The University Press of Kansas, Lawrence, 1968.

12. Pérez Escolar, M. E., Unpublished data.

13. Scott, L. B., The lima bean pod borers in Puerto Rico, J. Agr. Univ. P. R. 24(2): 35-47, 1940.

14. Wolcott, G. N., Lima bean pod borer caterpillars of Puerto Rico, J. Agr. Univ. P.R., 17 (3) : 241-55, 1933.

15. - Lima bean pod borer caterpillars of Puerto Rico on their wild hosts, J. Agr. Univ. P.R. 18(3) : 429-34, 1934.

16. - The insects of Puerto Rico, J. Agr. Univ. P. R. 32(1-4): 581-3, 647-70, 1948.

17. Wu Leung, W. T. and Flores, M., Tabla de composición de alimentos para uso en América Latina, Inst. Nutrición de Centro América y Panama, Guatemala, Guatemala, C.A., 1961. 